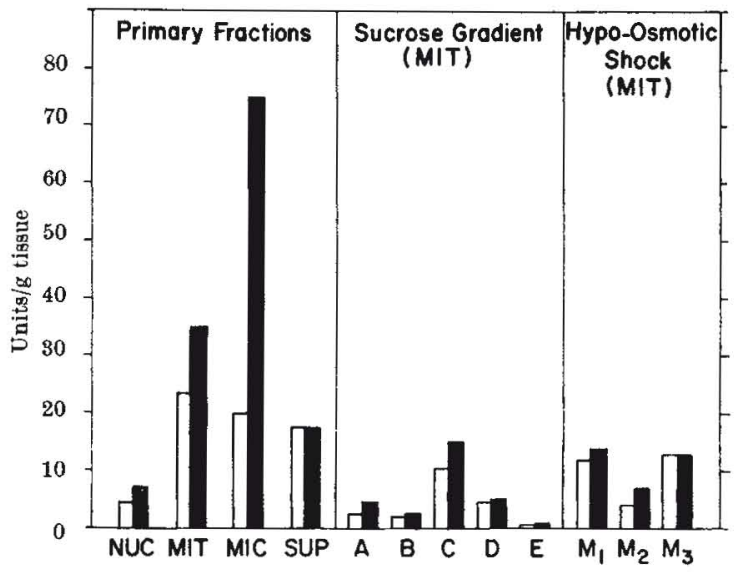

Fig. 2. Effect of 'Triton $X$-100' on unmasking of latent phosphodiesterase activity in various subcellular fractions. Fractions were prepare as usual and each raction was divided into two, one serving as control the other was diluted with 0.32 molar sucrose to a protein concentration of $5 \mathrm{mg} / \mathrm{ml}$. and then treated with $0 \cdot 2$ per cent 'Triton $X-100$ ' (final concentration). White block, control; solid block, "Triton'. Separate experiments established that this concentration of 'Triton' exposed al kept at $0^{\circ}$ for 30 min before be published). Both sets of samples were is expressed as units/g tissue. The total activity in the control exhibited 77 units/g tissue while that treated with 0.2 per cent "Triton' 122 units/g tissue. IResults are average of two experiments using a pool of ten braing in each experiment. Recovery of phosphodiesterase from the various fractions in these experiments was 80-85 per cent.

activities. With the exceptions of SUP and $M_{3}$, all fractions display an increase in activity. MIC was most pronounced, giving a 4 -fold increase. The increase in all other fractions could be caused by the small contamination by microsomes which would be expected. In the presence of 'Triton', MIC accounts for more than half the activity in the whole brain. The fact that there was no increase of activity in the soluble enzyme in SUP and $M_{3}$ would suggest that 'Triton' did not activate the enzyme as such, but possibly exposed the enzyme which would otherwise have been inaccessible during the assay. In order to see whether phosphodiesterase was associated with lysosometype particles, we submitted the microsomal fraction to vigorous mechanical disruption in a 'Vir'Tis 45' homogenizer for times up to $9 \mathrm{~min}$. Samples were taken at various intervals and no increase was observed in any of them. Repeated freezing and thawing of the microsomal fraction also caused no appreciable increase. More than 90 per cent of the activity was still attached to the sediment $(100,000 \mathrm{~g} \times 45 \mathrm{~min})$ after such physical disruption. Parallel treatment of the microsomes with 'Triton' gave the usual burst of activity. It seems that the latent enzymo might be embedded in the lipoprotein matrix of microsomes in such a manner that it could only be exposed by the detergent. In this respect, the behaviour of phosphodiesterase is different from acid phosphatase, a typical lysosomal enzyme, the latent activity of which could be released by all the treatments described above ${ }^{12}$. It is also different from cholinesterase in that the latter is a microsomal enzyme but shows no latent activity ${ }^{13}$.

Both MIC and $M_{1}$ are composed of membrane fragments, accounting for more or less the same amount of protein. Whereas there is virtually no effect of 'Triton' on the activity associated with $M_{1}$, the increase of activity in MIC amounts to 400 per cent, suggosting that phosphodiesterase might be preferentially distributed in certain membrane structures.

Drummond and Perrott-Yee ${ }^{14}$ reported that a cyclic $3^{\prime}, 5^{\prime}$-nucleotide phosphodiesterase from rabbit brain was localized entirely in the $100,000 \mathrm{~g}$ supernatant. Nair ${ }^{15}$ noted that a similar enzyme prepared from frozen dog heart was present exclusively in the supernatant. These observations are at variance with our data and those of Butcher and Sutherland, who found that phosphodiesterase from beef heart is mostly particulate. The reason for such a discrepaney is not apparent to us.
Our results indicate that phosphodiesterase as fractionated in isotonic sucrose solution does not exhibit its full potential activity. The majority of the activity in the microsomes is latent and is unmasked by the action of 'Triton', but not by mechanical disruption or repeated freezing and thawing. In the presence of 'Triton', micro. somes account for more than half the total activity. The remaining activity distributes about equally among synaptoplasm and a $100,000 \mathrm{~g}$ supernatant.

We thank Professor B. Chance for his interest and encouragement throughout the course of this investigation. We also thank Mrs. A. E. Strichartz for technical assistance. This work was supported by the U.S. Public Health Service.

Johnson Research Foundation,

WaI Yiu Cheung LeON SalganicofF*

University of Pennsylvania,

Philadelphia, Pennsylvania.

* Fellow of the Consejo Nacional de Investigaciones Cientificas y Tecnicas Republica Argentina.

1 Rall, T. W., and Sutherland, E. W., J. Biol. Chem., 237, 1228 (1962).

${ }^{2}$ Sutherland, E. W., and Rall, T. W., J. Biol. Chem., 232, 1077 (1958).

${ }^{3}$ Sutherland, E. W., Rall, T. W., and Menon, T., J. Biol. Chem., 28\%, 1220 (1962).

${ }^{4}$ Butcher, R. W., and Sutherland, E. W., J. Biol. Chem., 23\%, 1244 (1962).

${ }^{5}$ Cheung, W. Y., Biochem. Biophys. Res. Commun., 23, 214 (1966).

${ }^{6}$ De Robertis, E., Pellegrino de Iraldi, A., Rodriguez de Lores Arnaiz, G., and Salganicoff, L., J. Neurochem., 9, 23 (1962).

7 De Robertis, E., Salganicoff, L., Zieher, L. M., Rodriguez de Lores Arnaiz, G., J. Neurochem., 10, 255 (1963).

${ }^{8}$ Fiske, C. H., and Subbarow, Y., J. Biol. Chem., 66, 375 (1925).

'Lowry, O. H., and Lopez, J. A., J. Biol. Chem., 162, 421 (1946)

${ }^{10}$ De Robertis, E., in Histophysiology of Synapses and Neurosection, 122 (Pergamon Press, New York, 1964).

11 Salganicoff, L., and De Robertis, E., J. Neurochem, 12, 287 (1965).

${ }^{12}$ Sellinger, O. Z., Rucker, D. L., and De Balbian Verster, J. Neurochem., 11, 271 (1964).

1s Toschi, G., Exp. Cell Res., 16, 232 (1959).

${ }^{14}$ Drummond, G. I., and Perrott-Yee, S., J. Biol. Chem., 236, 1126 (1961).

${ }^{1 .}$ Nair, K. G., Biochemistry, 5, 150 (1985).

\section{Aminoacyltransferase Stimulation of Protein Synthesis by Pig Adrenal Polysomes}

Administration of adrenocorticotrophin in vivo increases the incorporation of ${ }^{14} \mathrm{C}$-glycine into protein by the supernatant of adrenal homogenates centrifuged at $15,000 \mathrm{~g}^{1}$. A factor of the soluble cell fraction $(105,000 \mathrm{~g}$ supernatant) has been shown to be rate limiting for in vitro protein synthesis and its activity is doubled by ACTH administration in rats. This factor was reported to be proteinaceous; its elution pattern from DEAE-cellulose columns ${ }^{2}$ was identical with liver aminoacyltransferase ${ }^{3}$. The increased activity of the microsomal fraction by treatment with ACTH was reported to be delayed compared with the soluble cell fraction ${ }^{4}$. Thus it was of interest to find whether polysomes, which are polymeres of ribosomes and messenger-RNA ${ }^{5,6}$, or the protein from the soluble adrenal cell fraction were rate limiting for protein synthesis.

When polysomes were incubated with constant amounts of soluble cell fraction, the incorporation of ${ }^{14} \mathrm{C}$-glycine increased only slightly and by no means in proportion to the amount of polysomes added. Thus incubation of polysomes with $0.4 \mathrm{ml}$. of $105,000 \mathrm{~g}$ supernatant $(80 \mathrm{mg}$ equivalents) showed the following incorporations. Polysomes: $0.1 \mathrm{ml}$. (240 c.p.m.); $0.2 \mathrm{ml}$. (269 c.p.m.); $0.4 \mathrm{ml}$. (337 c.p.m.); pclysomes omitted (179 c.p.m.) (for incubation conditions see Table 1). We conclude that the amount of polysomes and therefore the amount of messenger RNA present in the incubation mixture did not limit the rate of amino-acid incorporation.

The protein factor prepared from pig soluble adrenal cell fraction (Fig. 1) and likely to be aminoacyltransferase ${ }^{2}$ did, however, stimulate the incorporation of ${ }^{14} \mathrm{C}$-glycine by constant amounts of polysomes in approximate proportion to the amount added. Samples VI and VII (Fig. 1) con- 
Table 1. INCORPORATION OF "16-GLYCINE BX ADRENAL POLYSOMES AS STIMUIATED BY AMINOACYLTRANSFERASE<smiles>[Al][As]([As])[W]#[Al]</smiles>

$$
\begin{gathered}
0.2 \mathrm{ml} \\
270 \\
515 \\
754 \\
210 \\
255
\end{gathered}
$$

$0.4 \mathrm{ml}$.

208
1,288
1,835
$\mathbf{3 1 1}$

Polysomes were prepared from fresh pig adrenals 8,7 and $0.1 \mathrm{ml}=160 \mathrm{mg}$. equivalents (containing $0.78 \mathrm{mg}$ protein ${ }^{8}$ and approximately $1.8 \mathrm{mg}$ RNA were incubated with $0 \cdot 3 \mathrm{ml}$. $105,000 \mathrm{~g}$ supernatant of fresh pig adrenals $\left(60 \mathrm{mg}\right.$-equivalent). ${ }^{14} \mathrm{C}$-glycine, ATP, GTP, PEP and P-kinase were added
as in Fig. 1 . In this system 0.2 or $0.4 \mathrm{ml}$. of samples V-IX (Fig. 1) were assayed for stimulation of ${ }^{10} \mathrm{C}$-glycine incorporation in a total volume of $1.05 \mathrm{ml}$. $\left(60 \mathrm{~min}, 37^{\circ} \mathrm{C}\right)$. The complete system with no addition showed an incorporation of 209 c.p.m.; $105,000 \mathrm{~g}$ supernatant omitted and 5 c.p.m. when polysomes were omitted. Addition of $0.2 \mathrm{ml}$. of samples produced th IX, 208 c.p.m.

tained aminoacyltransferase and stimulated amino-acid incorporation when they were added to incubation mixtures (Table 1).

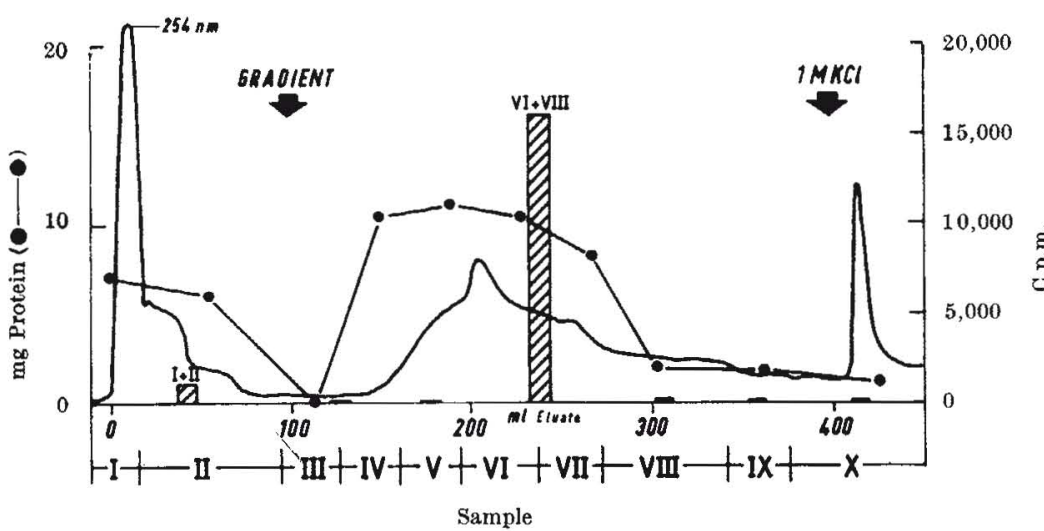

Fig. 1. Preparation of aminoacyltransferase from pig adrenals. $13.7 \mathrm{~g}$ fresh pig adrenals were homogenized in $68.5 \mathrm{ml}$. medium $A \quad(0.25$ molar sucrose, 0.025 molar potassium chloride, 0.005 molar magnesium chloride, 0.05 molar tris hydrochloric acid buffer, $p \mathbf{H} 7.5$ ) as described ${ }^{2}$ and the $105,000 \mathrm{~g}$ supernatant was passed through dextran gel ('Sephadex $\left.G-25^{\prime}\right)$. It was then concentrated by ultraflitration and subjected to anion exchange chromatography on a DEAE-cellulose column using a linear gradient made from 1: 0.03 molar potassium chioride, 0.02 molar tris hydrochlorle acid bufer, 02 molar th hach filtion tion of glycine (0.014 $\mu$ moles), $10 \mu$ moles phosphoenol-pyruvate, $1 \mu$ mole ATP, $0.25 \mu$ moles GTP, $60 \mu \mathrm{g}$ pyruvate kinase and $80 \mathrm{mg}$-equivalent of $1.05 \mathrm{ml}$. ( $\left(37^{\circ} \mathrm{C}, 60 \mathrm{~min}\right)$. The assay of ${ }^{14} \mathrm{C}$-glycine incorporated into protein was described earlier ${ }^{2}$. The data represent the total stimulation of incorporation in each sample (c.p.m.)

Adrenocorticotrophin administered to rats leads to increased protein synthesis in a cell-free system because of olevated activity or amount of aminoacyltransterase ${ }^{2}$. Only after continued treatment with ACTH is the activity of polysomes stimulated ${ }^{4}$, but aminoacyltransferase remains the rate limiting factor for in vitro protein synthesis.

This investigation was supported by the Deutsche Forschungsgemeinschaft.

\section{Peter C. Scriba} Martanne Fries

II. Medizinische Klinik der Universitat, Munich.

Received November 9, 1966.

${ }^{1}$ Farese, R. V., and Reddy, W. J., Endocrinology, 73, 294 (1963).

- Scriba, P. C., and Reddy, W. J., Endocrinology, 76, 745 (1965).

- Takanami, M., Biochim. Biophys. Acta, 51, 85 (1961).

- Farese, R. V., Endocrinology, 78, 125 (1966).

- Wettstein, F. O., Staehelin, T., and Noll, H., Nature, 197, 430 (1963).

- Gierer, A., J. Mol. Biol., 6, 148 (1963).

' Farese, R. V., Endocrinology, 77, 128 (1965).

- Lowry, O. R., Rosenbrough, N. J., Farr, A. L., and Randall, R. V., J. Biol.

- Dische, Z., in The Nucleic Acids (edit. by Chargaff, E., and Davidson, J. N.), 301 (Arademic Press, New York, 1955).

\section{IMMUNOLOGY}

\section{Inter Heavy-Light Chain Disulphide Bridge in Immune Globulins}

The immune globulins are a heterogeneous family of proteins made up of light and heavy* chains joined by disulphide bridges. Immunological techniques ${ }^{1,2}$ and chemical investigation ${ }^{3}$ indicate that most or all of the normal population of light chains is a mixture of two types of polypeptide- $x$ and $\lambda$. The majority of heavy chains can be classified as $\gamma, \mu$ or $\alpha$. In humans, the $\gamma$ chains have been further subdivided, making use of common antigenic determinants, into four major sub-classes: $\gamma^{2 a}$ (or $\mathrm{Ne}$ ), $\gamma^{2 b}$ (or $\mathrm{We}$ ), $\gamma^{2 c}$ (or $\mathrm{Vi}$ ), and $\gamma^{2 \mathrm{~d}}$ (or $\left.\mathrm{Ge}\right)^{4,5}$.

Combination of either $x$ or $\lambda$ chains with $\gamma, \mu$ or $\alpha$ chains gives rise to immune globulins IgG (gammalobulins), IgM (macroglobulins), or IgA. It has been postulated $^{3}$ that a single disulphide bridge linking $x$ or $\lambda$ chains to heavy chains occurs through the light chain C-terminal or next to C-terminal cysteine residue, and this has been based mainly on the arrangements of disulphide bridges in light chain monomers and dimers produced in the urine of myeloma patients (Bence-Jones proteins). A direct demonstration that this is the case has now been obtained by isolating disulphide-bridged peptides containing the C-terminal peptide of the light chain and a half-cystine peptide from the heavy chain of different types of human pathological immune globulins. In addition, a radioactive technique for the isolation of the corresponding carboxymethylcysteine peptides has been developed. This communication presents a comparison between peptides derived from different classes and sub-classes. Pooled normal IgG is shown to contain in good yields the peptides found in the two chief sub-classes of $\gamma$-chains.

Disulphide-bridged peptides were isolated by the performic acid oxidation diagonal technique ${ }^{6,7}$ after peptic (1/20 enzyme-substrate ratio in 5 per cent formic acid, $14 \mathrm{~h}$ at $37^{\circ} \mathrm{C}$ ) and then tryptic digestion (1/50 enzyme-substrate ratio in $p \mathrm{H}$ $7 \cdot 0,0.1$ molar ammonium acetate buffer, $6 \mathrm{~h}$ at $37^{\circ} \mathrm{C}$ ). Peptides were purified by paper electrophoresis at $p H$ 6.5 , and $p \mathrm{H} 3.5$ before and after oxidation; with the macroglobulin Ale, a preliminary fractionation of peptides on a 'Sephadex $G-25$ ' column in 2 per cent acetic acid was necessary. Peptides with the sequences shown in Table 1 were isolated from three different pathological immune globulins.

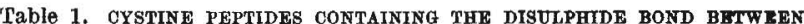
LIGHT AND HEAVY CHAINS OF SOME PATHOLOGICAT IMMUNE GLOBULTS Protein $\begin{aligned} & \text { Heavy Light } \\ & \text { chain chain } \\ & \text { type type }\end{aligned}$

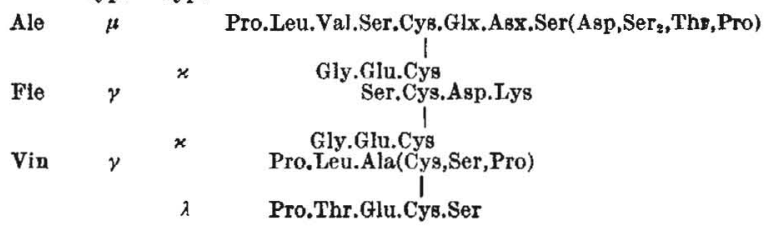

The occurrence of the sequences derived from Fie and Vin in pooled normal IgG and in other myeloma proteins

- The nomenclature used for immune globulin molecules, chalns and fragments is that recommended in ref. 24 . 